\title{
PREVALENCE OF SMOKING AND OTHER SMOKING-RELATED BEHAVIOURS AMONG STUDENTS AGED 13 TO 15 YEARS IN MONTENEGRO: RESULTS FROM THE GLOBAL YOUTH TOBACCO SURVEY OF 2008
}

\author{
Agima LJALJEVIĆ ${ }^{1}$, Elvir ZVRKO², Boban MUGOŠA ${ }^{1}$, Snežana MATIJEVIĆ ${ }^{3}$, and Jasmina \\ ANDJELIĆ ${ }^{3}$ \\ Institute of Public Health, Podgorical, Clinic for Otorhinolaryngology and Maxillofacial Surgery, Clinical Centre of \\ Montenegro, Podgorica ${ }^{2}$, Health Centre Tivat, Tivat ${ }^{3}$, Montenegro
}

\author{
Received in July 2009 \\ Accepted in March 2010
}

\begin{abstract}
The Global Youth Tobacco Survey (GYTS) is an international study that provides data on youth tobacco use for development of tobacco control programs. It is a school-based survey that uses a standardised methodology for sampling, core questionnaire items, training protocol, field procedures, and data management.

This article reports the findings from a GYTS conducted in Montenegro in 2008, which included 5723 adolescents. More than $30 \%$ of students aged 13 to 15 tried smoking, $5.1 \%$ smoked cigarettes, and $3.6 \%$ of students used tobacco products other than cigarettes. Four in 10 ever smokers started to smoke before the age of 10 . More than half the students reported secondary smoke exposure at home. Almost all $(96.5 \%)$ current smokers bought cigarettes in a store. Two in 10 students owned an artifact with a cigarette or tobacco brand logo on it.

The GYTS study has shown that there is an urgent need to introduce effective child-oriented smoking prevention programmes in early elementary school classes. These should be accompanied by public awareness campaigns on smoke-free homes.
\end{abstract}

KEY WORDS: GYTS, school-based survey, school health education, tobacco use, youth

Tobacco is one of the most important preventable causes of death in the world. Nearly five million deaths a year are caused by tobacco-related diseases, while that number is expected to more than double by the year $2020(1,2)$. By that time, $70 \%$ of those deaths will occur in developing countries (3).

Tobacco use in Montenegro is an escalating health and economic problem. Anecdotal information suggests that Montenegro is among the leading countries in terms of tobacco consumption. A UNICEF-sponsored health behaviour survey, conducted in 1999, showed a smoking prevalence of $3.9 \%$ among primary schoolchildren (11 to 14 years) and $19.7 \%$ among secondary school students aged 15 to 18 years (4).

Smoking prevalence seems to be on the rise among children and adolescents. Moreover, the World Health Organization (WHO) is concerned about the starting age is getting lower. In many countries the median starting age is less than 15 years. This is of particular concern, since early start increases the risk of death from a smoking-related disease. Among those who 
continue to smoke throughout their lives, about half can be expected to die from a smoking-related disease, with half of those deaths occurring at the middle age. Therefore, adolescents and schoolchildren should be the primary focus of anti-smoking strategies. The WHO, the Centers for Disease Control and Prevention (CDC), and the Canadian Public Health Association (CPHA) developed the Global Youth Tobacco Survey (GYTS) to assist all WHO member states in establishing a tobacco surveillance system (5).

This paper reports findings of a GYTS conducted in Montenegro in 2008 about the prevalence of tobacco use and smoking cessation, exposure to secondary smoke, tobacco industry marketing, access to and availability of tobacco products, and anti-smoking school curricula. The results are intended to help policy and decision makers issue better tobacco control policies, regulations and programmes.

\section{SUBJECTS AND METHODS}

\section{Study design}

GYTS is an international study intended to increase the understanding about students' attitudes, knowledge and behaviour related to tobacco use, its health impact, quitting smoking, environmental tobacco smoke, media and advertising, accessibility to minors, and anti-smoking school programmes. The GYTS provides a mechanism by which countries can monitor tobacco use among 13 to 15 -year-old students and implement and evaluate tobacco prevention and control programs. Its aim is to determine the rate of tobacco use among students; age of initiation of cigarette use; susceptibility to becoming cigarette smokers; and exposure to tobacco advertising. The survey seeks to identify key variables, such as attitudes and beliefs about tobacco use among young people, which can be used in prevention programs, and to assess to which extent school tobacco control programmes reach students and how they feel about them.

All GYTS surveys use exactly the same sampling procedures, core questionnaire items, training protocol, and field procedures $(6,7)$. Therefore, the analysis of data is consistent and comparable across all survey sites and over time.

The Montenegro GYTS 2008 is a school-based survey employing a two-stage cluster sample design to produce a national representative sample of students in elementary school grades 6, 7, and 8 (ages 12 to 14) and secondary school grade 1 (age 15). The survey included twenty schools from the capital of Podgorica (counting one third of the national population) and twenty schools from rural areas. Classes from each school were selected using the equal probability method. All students in the selected classes were eligible to participate in the survey. Participation was anonymous and voluntary. Students self-administered the questionnaire in the classroom by answering to 88 multiple-choice questions on a sheet that was later scanned by a computer.

The questions were about their awareness of and attitudes toward cigarette smoking, the influence of the media and advertising on their use of cigarettes, about access to cigarettes, about anti-smoking teaching programmes at schools, about exposure to environmental tobacco smoke, and about quitting smoking cigarettes.

Current use of cigarettes was defined as having smoked at least once during the 30 days preceding the survey. The fieldwork was carried out from February to May 2008. A weighting factor was applied to each student record to adjust for non-response and for the varying probabilities of selection at the school and class levels. A software package for statistical analysis of correlated data SUDAAN was used to compute standard errors of the estimates and $95 \%$ confidence intervals.

\section{RESULTS}

School response rate was $100.0 \%$. All classes in the selected schools were included in the sampling frame and the response rate was $99.69 \%$. Student response rate was $93.19 \%$; 5723 of 6141 students completed the questionnaire. Among them, $48.2 \%$ were boys and $51.8 \%$ girls.

\section{Prevalence and Cessation}

At the time of the GYTS, $31.3 \%$ of 13 to 15 -yearold students in Montenegro had ever smoked cigarettes (Table 1): $31.9 \%$ girls and $30.7 \%$ boys. About 4 in 10 ever smokers of either sex started before the age of 10. $5.1 \%$ of students in Montenegro currently smoked cigarettes: $5.7 \%$ boys and $4.4 \%$ girls. $3.6 \%$ of the students currently used tobacco products other than manufactured cigarettes (that is, hand-rolled cigarettes, 
Table 1 Prevalence of smoking and other smoking-related behaviours, susceptibility to smoking among students who had never smoked, and the wish to quit smoking among current smokers (Montenegro GYTS, 2008)

\begin{tabular}{lccc}
\hline \multirow{2}{*}{ Students who: } & \multicolumn{3}{c}{ Prevalence / \% $(\mathbf{9 5} \% \mathbf{C I})$} \\
\cline { 2 - 4 } & $31.3(27.3$ to 35.7$)$ & $30.7(27.1$ to 34.7$)$ & $31.9(25.7$ to 38.7$)$ \\
\hline $\begin{array}{l}\text { Ever smoked cigarettes } \\
\text { Smoked cigarettes before the age } \\
\text { of } 10 \text { (among ever smokers) }\end{array}$ & $39.6(34.6$ to 44.9$)$ & $40.6(34.4$ to 47.0$)$ & $38.8(32.9$ to 45.0$)$ \\
$\begin{array}{l}\text { Current cigarette smoker } \\
\text { Current user of other tobacco }\end{array}$ & $5.1(4.0$ to 6.4$)$ & $5.7(4.3$ to 7.6$)$ & $4.4(3.1$ to 6.1$)$ \\
$\begin{array}{l}\text { products } \\
\text { Never smokers likely to start }\end{array}$ & $3.6(2.9$ to 4.5$)$ & $3.7(2.6$ to 5.2$)$ & $3.5(2.6$ to 4.8$)$ \\
$\begin{array}{l}\text { smoking in the year that follows } \\
\text { Current smokers who always feel }\end{array}$ & $16.0(14.1$ to 18.2$)$ & $15.7(12.3$ to 19.9$)$ & $16.5(13.9$ to 19.4$)$ \\
$\begin{array}{l}\text { like having a cigarette first thing } \\
\text { in the morning }\end{array}$ & $7.9(3.7$ to 16.0$)$ & $12.0(5.0$ to 25.9$)$ & $2.1(0.2$ to 16.1$)$ \\
$\begin{array}{l}\text { Current smokers who wanted to } \\
\text { quit }\end{array}$ & $41.2(30.9$ to 52.3$)$ & $39.9(26.2$ to 55.5$)$ & $*$ \\
\hline
\end{tabular}

* less than 35 cases (statistical tests were not performed)

cigars, mini cigars, cigarillos, pipes, chew, snuff, or dip). Less than $8 \%$ of current cigarette smokers reported they felt like having a cigarette first thing in the morning (indicative of cigarette dependency). Among never smokers, $16 \%$ reported that they saw themselves smoke within a five years time. Among students who currently smoked cigarettes, $41.2 \%$ reported they wanted to stop smoking now.

\section{Exposure to secondary smoke}

More than a half $(60.3 \%)$ of students reported they were exposed to secondary smoke at home. $69.9 \%$ reported exposure in public places. Current smokers were significantly more exposed to smoke in public places than non-smokers. Most of the students $(89.8 \%)$ thought smoking should be banned in public places (Table 2 ). Significantly more non-smokers than smokers supported that smoking should be banned in public places.

\section{School programmes about the dangers of tobacco use}

More than half of all students (56.0\%), more girls than boys, reported that they had been taught about the dangers of tobacco over the past school year (Table 2).

\section{Accessibility and exposure to indirect advertising}

In the month before the survey (Table 2), almost all $(96.5 \%)$ students who currently smoked reported that they "usually" bought their cigarettes in a store in spite of their minor age; $89.8 \%$ reported seeing an anti-smoking media message; $47.4 \%$ reported that they saw tobacco advertisements on billboards; $58.2 \%$ reported seeing advertisements for cigarettes in newspapers or magazines; and $20.2 \%$ reported that they had an object such as a hat, t-shirt, knapsack, or pen with a cigarette or tobacco brand logo on it. More boys than girls had such objects. Overall, $19.3 \%$ of students had been offered free cigarettes by a tobacco company representative at any time, boys more often than girls.

\section{DISCUSSION}

The 2008 Montenegro GYTS investigated a wide range of issues related to tobacco use in schoolchildren aged 13 to 15 . Its data may come in useful for policymakers and action programmes of tobacco control. The known risk factors of cigarette smoking among adolescents include age (8), male gender (8$10)$, having smoking friends (11), parental smoking (10), perception that smoking is not harmful (12), and the amount of pocket money (10).

Our GYTS data show that more than $30 \%$ of students aged 13 to 15 have tried smoking. An even more alarming finding is that 4 in 10 smokers started it at the age of 10 years. This suggests that anti-tobacco campaigns should also target primary school students, and especially the fifth and sixth grades. 
Table 2 Prevalence of factors that influence smoking and other smoking-related behaviours (Montenegro GYTS, 2008)

\begin{tabular}{|c|c|c|c|}
\hline \multirow{2}{*}{ Students who: } & \multicolumn{3}{|c|}{ Prevalence / \% (95 \% CI) } \\
\hline & Total & Male & Female \\
\hline One or more parents smoke & $60.3(57.5$ to 63.0$)$ & $58.9(55.6$ to 62.1$)$ & $62.0(58.8$ to 65.1$)$ \\
\hline All or most best friends smoke & $11.5(9.1$ to 14.4$)$ & $12.2(9.9$ to 14.9$)$ & $11.0(7.8$ to 15.3$)$ \\
\hline Exposed to smoke in public places & $69.9(67.7$ to 72.0$)$ & $68.8(65.8$ to 71.6$)$ & $70.8(67.7$ to 73.8$)$ \\
\hline $\begin{array}{l}\text { Exposed to smoke in public places } \\
\text { (among non-smokers) }\end{array}$ & $65.6(63.6$ to 67.5$)$ & $63.9(61.0$ to 66.6$)$ & $67.2(64.5$ to 69.9$)$ \\
\hline $\begin{array}{l}\text { Exposed to smoke in public places } \\
\text { (among smokers) }\end{array}$ & $91.2(84.5$ to 95.2$)$ & $87.7(76.2$ to 94.1$)$ & $95.1(81.3$ to 98.9$)$ \\
\hline $\begin{array}{l}\text { Thought smoking should be banned } \\
\text { in public places }\end{array}$ & $89.8(87.9$ to 91.5$)$ & $88.8(87.2$ to 90.3$)$ & $91.0(87.4$ to 93.6$)$ \\
\hline $\begin{array}{l}\text { Thought smoking should be banned } \\
\text { in public places } \\
\text { (among non-smokers) }\end{array}$ & 94.8 (93.4 to 95.9$)$ & $93.4(91.3$ to 95.0$)$ & $96.3(94.4$ to 97.6$)$ \\
\hline $\begin{array}{l}\text { Thought smoking should be banned } \\
\text { in public places (among smokers) }\end{array}$ & $55.2(47.2$ to 65.3$)$ & $55.5(45.2$ to 65.3$)$ & $55.2(41.8$ to 67.9$)$ \\
\hline $\begin{array}{l}\text { Were taught the dangers of smoking } \\
\text { in schools in the year prior to the } \\
\text { survey }\end{array}$ & $56.0(51.6$ to 60.3$)$ & $53.4(49.5$ to 57.3$)$ & $59.0(53.4$ to 64.3$)$ \\
\hline $\begin{array}{l}\text { Usually bought cigarettes } \\
\text { in a store (among smokers) }\end{array}$ & $96.5(86.0$ to 99.2$)$ & $*$ & $*$ \\
\hline $\begin{array}{l}\text { Ever offered a free cigarette by a } \\
\text { cigarette company representative }\end{array}$ & 19.3 (17.6 to 21.2$)$ & $21.9(19.9$ to 24.0$)$ & $16.8(14.3$ to 19.7$)$ \\
\hline $\begin{array}{l}\text { During the past month saw any } \\
\text { anti-smoking media messages }\end{array}$ & 89.8 (87.9 to 91.4$)$ & 90.4 (88.0 to 92.4$)$ & $89.3(87.0$ to 91.3$)$ \\
\hline $\begin{array}{l}\text { During the past month saw } \\
\text { any cigarette advertisement in } \\
\text { newspapers/magazines }\end{array}$ & $58.2(55.2$ to 61.1$)$ & $58.3(54.3$ to 62.2$)$ & 58.1 (53.8 to 62.2$)$ \\
\hline $\begin{array}{l}\text { Have an object (t-shirt, pen, } \\
\text { backpack, etc.) with a tobacco } \\
\text { brand logo on it }\end{array}$ & $20.2(18.2$ to 22.3$)$ & $22.6(19.9$ to 25.5$)$ & $18.0(15.7$ to 20.5$)$ \\
\hline
\end{tabular}

* less than 35 cases (statistic tests were not performed)

Our study has also shown that the $5 \%$ rate of currently smoking students in Montenegro is lower than the overall GYTS rate (8.9\%) (2) or the rate in Greece $(10.4 \%)$, Thailand $(10.1 \%)$ or Peru $(15 \%)$ (13-15). Our results are consistent with data from earlier studies conducted in Montenegro $(4,16)$. Once they enrol in secondary school, students seem to start smoking due to several factors, including a selfperception of greater independence, the influence of peers, and a desire to imitate "adult" behaviour. The $16 \%$ prevalence of susceptibility to smoking among never smokers suggests that adolescents smoking rates may increase dramatically in the next few years. In Turkey, about $17.8 \%$ of boys and $14.4 \%$ of girls nonsmokers are open to the idea of smoking (17).

Our study has also shown that more than $3 \%$ of the students currently use tobacco products other than cigarettes, such as cigars and pipes. This kind of behaviour is new to Montenegro and calls for attention.

School-based tobacco prevention programmes are believed to give the best opportunity to prevent tobacco use because they reach most children. Unfortunately, this opportunity has not been used often enough in Montenegro. Only about half the schoolchildren were informed about the dangers of smoking and these data do not speak about the quality of the information provided to them.

The fact is that almost half the current student smokers wish to quit smoking. This suggests that there is a real need to develop and implement effective smoking cessation programs for the youth.

Data on secondary tobacco smoke show significant exposure at home. There is a significant difference 
between never smokers and current smokers in exposure to secondary smoke in public places because current smokers usually spend time with persons who smoke.

Almost all never smokers think that smoking should be banned from public places and only half the current smokers share this opinion. Students do not know enough about the impact of secondary smoke on their health; half of never smokers and one fourth of smokers in primary schools and one third of smokers in secondary schools think that smoke from others is definitely harmful to them.

Almost all students saw at least one anti-smoking media message in the month preceding the survey. More than a half of the students saw a cigarette advertisement in the newspapers or magazines from countries where direct advertising is not banned. Nearly $70 \%$ of students in Peru saw tobacco advertising on billboards or in newspapers or magazines (15). In addition, global tobacco companies indirectly advertise by giving away objects with tobacco brand logos such as t-shirts, backpacks, hats, and so on, which is illegal in Montenegro. Two in ten students in Montenegro reported that they had an object with a cigarette or tobacco brand logo on it.

The 2004 Montenegrin law prohibits selling tobacco products to youth under 18 years of age. However, this seems not to have limited access to cigarettes for them. Almost all of current smokers buy cigarettes in a store. Similarly, $95 \%$ of students in Greece buy cigarettes in stores (13).

We acknowledge certain limitations to this study. First, the sample included only the youth who were at school on the day of the. Second, the data are based on self-reports of students, who may under- or overreport their use of tobacco. Despite these limitations, the survey has provided valuable information about tobacco use patterns in Montenegrin youth.

\section{CONCLUSIONS}

This GYTS study has shown that schoolchildren smoking is indeed a problem in Montenegro, and that this issue should be taken seriously by decisionmakers, public health workers, teachers, parents, and the community at large. Smoking in our country is accepted at home, in school, in the street, and in other public places. As the respondents are at a very susceptible age, this attitude can be decisive for their decision to become smokers.
As nearly all children are enrolled in primary schools, there is an urgent need to introduce effective child-oriented smoking prevention programmes to low primary school grades and to continue them throughout secondary school.

While prevention should remain in the centre of activities, effective quitting programmes also deserve much attention, because smoking children have unambiguously indicated that they wish to quit smoking. Last but not least, public awareness campaigns for smoke-free homes should be developed and implemented.

\section{REFERENCES}

1. Peto R, Lopez AD. Future worldwide health effects of current smoking patterns. In: Koop CE, Pearson CE, Schwarz MR, editors. Critical issues in global health. San Francisco (CA): Jossey-Bass; 2001.

2. Warren CW, Jones NR, Eriksen MP, Asma S; Surveillance System (GTSS) collaborative group. Patterns of global tobacco use in young people and implications for future chronic disease burden in adults. Lancet 2006;367:749-53.

3. Peto R, Lopez AD, Boreham J, Thun M, Heath CJr. Mortality from Smoking in Developed Countries 1950-2000: Indirect Estimation from National Vital Statistics. Oxford: Oxford University Press; 1994.

4. Laušević D, Mugoša B, Ljaljević A. Istraživanje stavova i ponašanja školske djece i omladine o bolestima zavisnosti, seksualnosti i ishrani u republici Crnoj Gori [The survey of attitude and behavior of school children and youth about addiction disease, sexuality and nutrition in Montenegro, in Montenegrin]. Podgorica: Institute of Public Health; 1999.

5. The Global Tobacco Surveillance System Collaborating Group. The global tobacco surveillance system (GTSS): purpose, production and potential. J Sch Health 2005;75:1524.

6. Warren CW, Riley L, Asma S, Eriksen MP, Green L, Blanton C, Loo C, Batchelor S, Yach D. Tobacco use by youth: a surveillance report from the Global Youth Tobacco Survey project. Bull World Health Organ 2000;78:868-76.

7. The GYTS Collaborating Group. Differences in worldwide tobacco use by gender: findings from the Global Youth Tobacco Survey. J Sch Health 2003;73:207-15.

8. Abdullah AS, Ho WW. What Chinese adolescents think about quitting smoking: a qualitative study. Subst Use Misuse 2006;41:1735-43.

9. Hublet A, De Bacquer D, Valimaa R, Godeau E, Schmid H, Rahav G, Maes L. Smoking trends among adolescents from 1990 to 2002 in ten European countries and Canada. BMC Public Health 2006;6:280.

10. Rachiotis G, Muula AS, Rudatsikira E, Siziya S, Kyrlesi A, Gourgoulianis K, Hadjichristodoulou C. Factors associated with adolescent cigarette smoking in Greece: results from a cross sectional study (GYTS Study). BMC Public Health 2008;8:313.

11. Rudatsikira E, Muula AS, Siziya S, Mataya RH. Correlates of cigarette smoking among school-going adolescents in 
Thailand: findings from the Thai global youth tobacco survey 2005. Int Arch Med 2008;1:8-13.

12. Rudatsikira E, Abdo A, Muula AS. Prevalence and determinants of adolescent tobacco smoking in Addis Ababa, Ethiopia. BMC Public Health 2007;7:176-82.

13. Kyrlesi A, Soteriades ES, Warren CW, Kremastinou J, Papastergiou P, Jones NR, Hadjichristodolou C. Tobacco use among students aged 13-15 years in Greece: the GYTS project. BMC Public Health 2007;7:3.

14. Sirichotiratana N, Techatraisakdi C, Rahman K, Warren CW, Jones NR, Asma S, Lee J. Prevalence of smoking and other smoking-related behaviors reported by the Global Youth Tobacco Survey (GYTS) in Thailand. BMC Public Health 2008;8(Suppl 1):S3.
15. Zavaleta A, Salas M, Peruga A, Hallal AL, Warren CW, Jones NR, Asma S. Prevalence of smoking and other smoking related behaviors reported by the Global Youth Tobacco Survey (GYTS) in four Peruvian cities. BMC Public Health 2008;8(Suppl 1):S2.

16. Ljaljević A, Zvrko E, Stojiljković M. Tobacco use among youth: findings from the Global Youth Tobacco Survey in Montenegro. Arh Hig Rada Toksikol 2008;59:183-9.

17. Ertas N. Factors associated with stages of cigarette smoking among Turkish youth. Eur J Public Health 2007;17:15561. 


\section{Sažetak}

ZASTUPLJENOST PUŠENJA I PUŠAČKE NAVIKE UČENIKA DOBI 13 DO 15 GODINA U CRNOJ GORI: REZULTATI GLOBALNOG ISTRAŽIVANJA O POTROŠNJI DUHANA KOD MLADIH (GYTS) 2008.

Globalno istraživanje o potrošnji duhana kod mladih (GYTS) međunarodna je studija koja pruža podatke o pušačkim navikama mladih i omogućava razvijanje programa čiji je cilj kontrola duhana. U ovom radu dati su rezultati istraživanja GYTS koje je provedeno 2008. godine u Crnoj Gori.

Istraživanje GYTS provodi se u školama pri čemu je standardizirana metodologija za formiranje uzorka, upitnik, prikupljanje i obrada podataka. Ukupno su 5723 učenika sudjelovala u istraživanju.

Više od 30 \% učenika dobi 13 do 15 godina eksperimentiralo je cigaretama. U ovoj populaciji ima $5.1 \%$ stalnih pušača cigareta, dok $3.6 \%$ učenika koristi neke druge duhanske proizvode. Četiri od 10 pušača počela su pušiti prije desete godine života. Više od pola ispitanika odgovorilo je da su izloženi duhanskom dimu u svojoj kući. Gotovo svi pušači (96.5 \%) najčešće kupuju cigarete u prodavaonicama. Dva od 10 ispitanika imaju neki predmet s logom proizvođača cigareta.

Rezultati istraživanja pokazuju da je potrebno hitno pokrenuti preventivne programe kontrole duhana u nižim razredima osnovne škole. Također, potrebno je osmisliti i implementirati kampanje čiji je cilj podizanje svijesti građana o štetnosti pušenja u zatvorenom prostoru.

KLJUČNE RIJEČI: GYTS, mladi, školsko istraživanje, upotreba duhana, zdravstvena edukacija u školi

CORRESPONDING AUTHOR:

\section{Elvir Zvrko}

Clinic for ORL and MFS

81000 Podgorica, Montenegro

E-mail:elvir@zvrko.me 